\title{
Acceptability of the Equivalent Static Method for Designing Multi-Story Structures
}

\author{
Restu Faizah $^{1 *}$, Bagus Soebandono ${ }^{1}$, N. M. Iskandar Sugeha ${ }^{1}$ \\ ${ }^{I}$ Department of Civil Engineering, Universitas Muhammadiyah Yogyakarta, Indonesia \\ *Corresponding author.Email: restu.faizah@umy.ac.id
}

\begin{abstract}
Equivalent static is a simplification method to design earthquake loads that must be calculated in the structural design. This method is practical and easy to apply, but only appropriate for low structures with high rigidity. The structures having low rigidity and irregularity in geometry must be analyzed using the time history method. This paper aims to investigate how high structures are still allowed to be designed using equivalent static earthquake loads. The investigation was carried out by comparing the equivalent static analysis results with time history analysis results representing the reality. The structure models were four 2D open resistant concrete frames, with 7, 9,10 and 15 stories. The analysis used the SAP2000 program resulting in structure responses, including story horizontal forces, base shear, story shear forces, and story displacement. The analysis revealed that a 9 -story or higher structures were not acceptable if designed using an equivalent static method. Thus, they must be analyzed using the time history method. The potential damage of structures designed using equivalent static methods was estimated at the bottom areas. These results can be used as a consideration to determine an analysis method in earthquake-resistant structural design.
\end{abstract}

Keywords - Equivalent static method, multi-story structure, time history method

\section{INTRODUCTION}

Determining of the structural response under earthquake is not simple due to random and fast seismic vibrations in the base structure. Earthquake forces spreads in all directions and partly propagates to the ground surface, then vibrates the ground around the base building. The ground acceleration affected by the earthquake is non-periodic (random), nonharmonic, and tends to fluctuate, as shown in the time history of the El-Centro Earthquake in Fig. 1. Ground acceleration is a dynamic load of which the intensity fluctuates with time so that the ground acceleration effect on the structure is also inconstant. Therefore, the structural response of the building under earthquake must be determined by dynamic analysis. Time history analysis is the most accurate dynamic method to analyze the structural response under an earthquake, but it requires many computations, hence taking much time. Equivalent static analysis is commonly used for practical purposes, simplifying the dynamic analysis and considering only the first vibration mode of the structure [1].

Paz and Leigh [2] stated two methods for earthquakeresistant design: the lateral force (static) method and the dynamic method. The static method is applied for regular structures under $73 \mathrm{~m}$ in height or irregular structure at least $20 \mathrm{~m}$ in height. Other structures not meeting these requirements must be analyzed by the dynamic method. The structure with fundamental periods greater than $0.7 \mathrm{sec}$ must also be analyzed by the dynamic method.



Fig. 1. Strong motion record of El-Centro Earthquake (1940)

The static analysis is based on several assumptions, which are: (i) the structure assumed to be rigid, (ii) the fixed bond between the structure and foundation is assumed perfect, (iii) every section of structure experience the same accelerations during ground motion, (iv) effect of an earthquake is assumed as a horizontal force on certain loading point, and (v) the base shear force is approximately determined as the total of horizontal force on the structure. The main difference between static and dynamic concepts is the building characteristics considered in the analysis. The dynamic concept considers a mass, stiffness, and attenuation (damping), while the static concept is just a mass. Consequently, it requires simplification and assumption in the equivalent static analysis. These static formulas were designed to represent the dynamic behavior of the regular structures (Structures having a uniform distribution of mass and stiffness) [3]. 
The dynamic analysis represents the real conditions, where the mass of the building, stiffness, and earthquake intensity change over time, and damping is considered in the analysis. Time history analysis can estimate the dynamic response of a structure under dynamic loading. Time history represents reality and provides a better safety of structures if compared with the structures analyzed and designed by an equivalent static method [4].

Time history analysis utilizes an acceleration record as an earthquake load. This recording must be taken from the site having a similar condition with the building structure site, including geology, topography, or seismo-tectonic condition. SNI 1726:2012 requires non-regular structures to be analyzed using a time history method. The non-regular structures have more than 10 stories $(40 \mathrm{~m})$ in height and a horizontal or vertical irregularity [5]. Unfortunately, the time history method is a complicated analysis requiring much time. Many people prefer the equivalent static analysis to design the earthquake loads in the structural design, even for the nonregular buildings. As a result, structures that could not withstand a massive earthquake were discovered. Based on this fact, the study to clarify the acceptance of the equivalent static method must be improved.

Nasution and Teruna [6] stated that the equivalent static method is permitted to analyze the 7-story building, but the dynamic analysis is better due to more accuracy. Bagheri [7] also confirmed that time history analysis is an appropriate method to visualize building's performance level of under an earthquake, while equivalent static is inadequate for high-rise buildings. There is a significant difference in the displacement values from equivalent static and time history analysis, mainly in lower stories.

Other research shows that the equivalent static method was accepted to analyze the 5-story frame, but not for the 10-story and higher frames. This research recommends that a 10-story and higher building structural design must take a time history method on the analysis. The equivalent static method is solely recommended for less than a 10-story building analysis. This research does not present the definite limit of the acceptability between 5 and 10 stories, thereby requiring further studies to investigate it [8].

Based on the previous research, a study is needed to investigate the acceptability of the equivalent static method, especially on the structure between 7 and 10 stories. Therefore, this research examined the acceptability of the equivalent static method on the 7,9 and 10-story structures. Besides, the 15-story structure was also investigated as a comparison

\section{METHODOLOGY}

This study analyzed a structural model that is loaded by earthquake forces to obtain structural responses such as story horizontal forces, basic shear, story shear forces, and displacements. Two analysis methods were performed: the equivalent static (ES) and the time history (TH). The results of ES analysis were validated using TH analysis by comparing the results between them. ES analysis is acceptable if the result is greater than $\mathrm{TH}$. If the results show otherwise, ES analysis is considered unsafe, as it provides fewer structural design requirements.

\subsection{Structural model}

The structure model in this study is a $2 \mathrm{D}$ reinforced concrete frame, a part of an actual building. Four structural models consisting of 7, 9, 10, and 15-story structures. The actual building specifications taken as a structural model are presented in Table I, while the illustration of the concrete frame of the structure is given in Fig. 2-5. For analysis purposes, assumptions are required, as described in Table II.

\subsection{Equivalent Static (ES) Method}

Using the ES method, earthquake load analysis refers to the 2019 seismic code, an earthquake-resistant design procedure for buildings and non-building [9]. The base shear resulted from the analysis is distributed over each floor as a story horizontal force. Furthermore, story shear and deflection can also be calculated. This analysis is very simple and can be performed using the excel program. Overall, the equivalent static analysis consists of the following stages.

a) The Determination of structural properties comprises stiffness $(k)$, weight $(W)$, and fundamental period $(T)$.

b) The determination of the building priority factor $(I)$ and the response modification coefficient $(R)$ is based on the 2019 seismic code.

c) The determination of the design parameters of the response spectra consists of bedrock acceleration in a short period $\left(S_{S}\right)$ and 1 second period $\left(S_{l}\right)$, soil type, and location parameters $\left(S_{M S}, S_{M I}, F_{a}, F_{V}, S_{D S}, S_{D I}\right)$. $S_{S}$ and $S_{I}$ are determined from the earthquake hazard map in the 2019 seismic code, presented in Fig. 6 for $S_{S}$ and Fig. 7 for $S_{l}$.

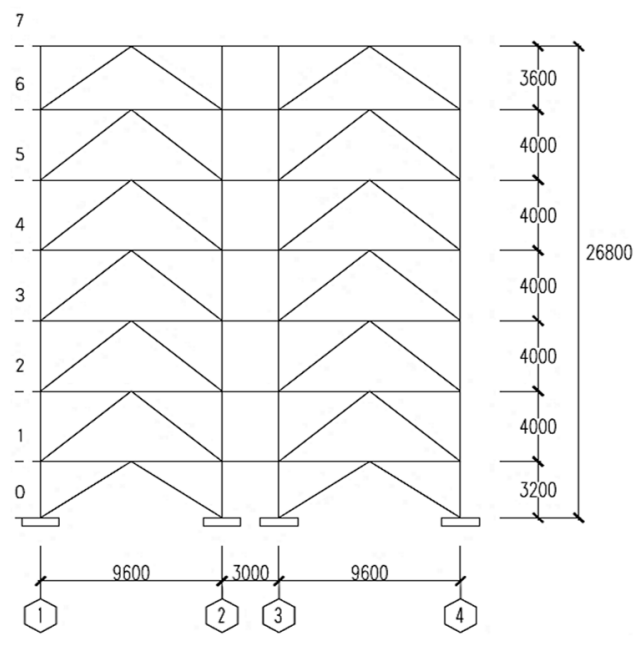

Fig 2. Concrete frame of the 7-story structure 
9



,4000,3200,4000 4475,

(1) (2) (3) 5

Fig 3. Concrete frame of the 9-story structure

。



$\nmid 3000,6000,6000,3000$,

Fig 4. Concrete frame of the 10-story structure

is

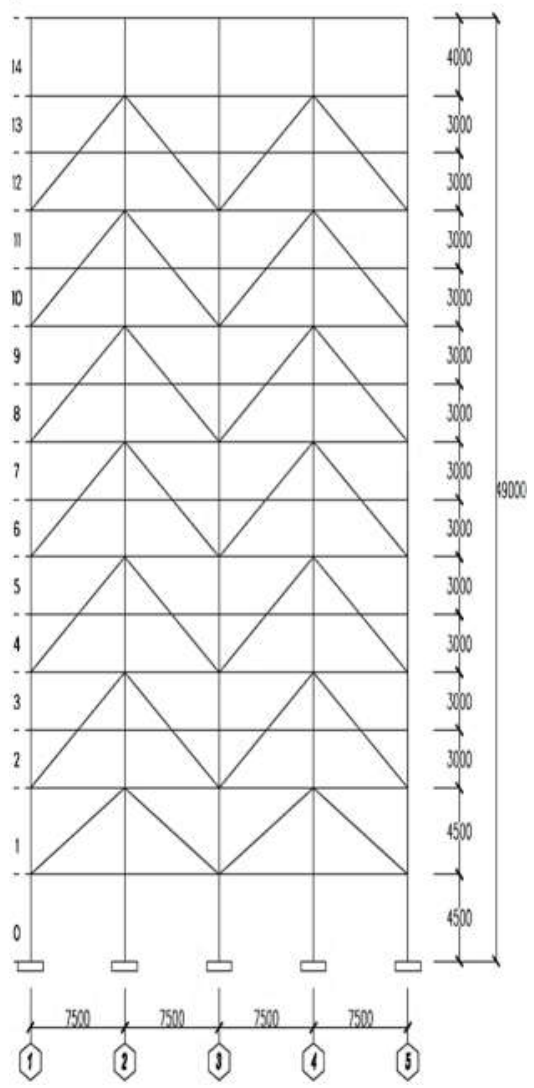

Fig 5. Concrete frame of the 15-story structure

Table I. The real structure taken as a structure model

\begin{tabular}{|c|c|l|c|}
\hline No. & $\begin{array}{c}\text { Number } \\
\text { of stories }\end{array}$ & Name of the actual building & $\begin{array}{c}\text { Building } \\
\text { Height } \\
(\mathbf{m})\end{array}$ \\
\hline 1 & 7 & Twin building E-7 UMY & 26.8 \\
\hline 2 & 9 & POP Hotel building & 30.2 \\
\hline 3 & 10 & $\begin{array}{l}\text { PT Halim Sakti office } \\
\text { building }\end{array}$ & 41.1 \\
\hline 4 & 15 & Star Hotel building & 49 \\
\hline
\end{tabular}

Table II. Assumptions in the analysis

\begin{tabular}{|c|l|c|}
\hline No. & \multicolumn{1}{|c|}{ Specification } & The value \\
\hline 1 & Steel strength $(\mathrm{BJ}-37) \mathrm{f}_{\mathrm{y}} / \mathrm{f}_{\mathrm{u}}$ & $240 / 370 \mathrm{MPa}$ \\
\hline 2 & Modulus of elasticity $\left(\mathrm{E}_{\mathrm{s}}\right)$ & $200,000 \mathrm{MPa}$ \\
\hline 3 & Modulus of rigidity $(\mathrm{G})$ & $77,200 \mathrm{MPa}$ \\
\hline 4 & Poisson's ratio $(\mu)$ & 0.3 \\
\hline 5 & Specific gravity of steel & 7,850 \\
\hline 6 & $\begin{array}{l}\text { Specific gravity of } \\
\text { concrete }\end{array}$ & 2,400 \\
\hline
\end{tabular}

d) The determination of the seismic response coefficient $(C)$ was carried out using Eq. (1). The $C$ value cannot be more than $C_{\max }$ and cannot be less than $C_{\min }$, as explained in Eq. (2-3). 


$$
C=\frac{S_{D S}}{\left(\frac{R}{l}\right)}
$$

(1)

$$
\begin{gathered}
C_{\max }=\frac{S_{D 1}}{T\left(\frac{R}{T}\right)} \\
c_{m m}=0.04 .4 . S_{12 .} . l \quad \geq 0.01
\end{gathered}
$$

$S_{D S}$ and $S_{D I}$ are parameters of spectra response design, $R$ is a response modification coefficient, $I$ is a building priority factor, and $T$ refers to a fundamental structure period.

e) The base shear calculation was performed using Eq. (4).

$$
V=C . W
$$

$V$ is base shear, $C$ is the seismic response coefficient, and $W$ is the weight of the structure.

f) The vertical distribution calculation of base shear was conducted using Eq. (5).
(5)

$$
F_{i}=\frac{W_{i}, h_{i}^{k}}{\sum W_{i} h_{i}}
$$

$F_{i}$ is the story horizontal force at $i$-story, $W_{i}$ is the weight of structure at $i$-story, and $h_{i}$ is the height of a structure at $i$-story.

The determination of the story deflection and story shear was performed using Eq. (6) and (7).

$$
d_{i}-\frac{F_{l}}{k_{i}}
$$

\section{(7)}

$$
V_{l}=\sum_{i}^{n} F_{t}
$$

$d_{i}$ is deflection at $i$-story, $F_{i}$ is the horizontal force at $i$ story, $k_{i}$ is stiffness at $i$-story, $V_{i}$ is the shear force at $i$-story, and $n$ is the number of stories.

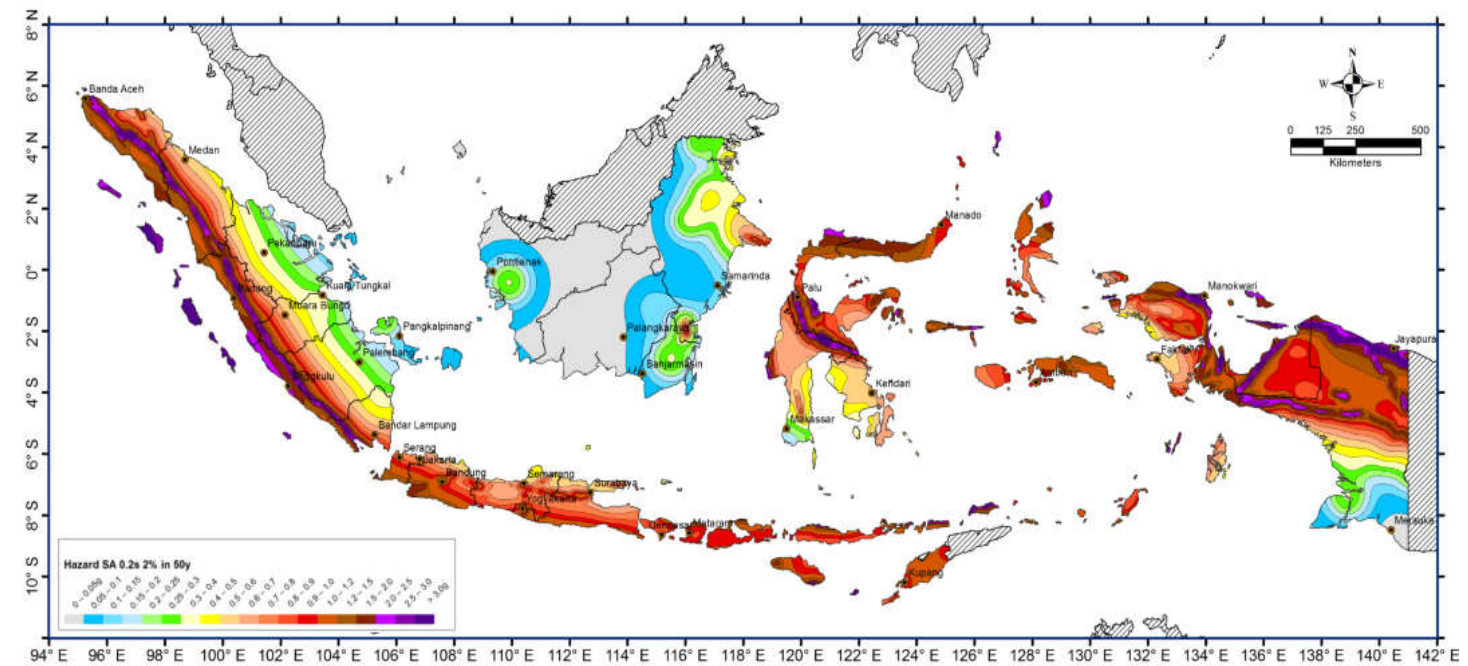

Fig 6. Map of the spectral response acceleration over a 0.2 second period, with $5 \%$ attenuation in bedrock $\left(S_{s}\right)$ for a $2 \%$ probability of being exceeded in 50 years [9]



Fig 7. Map of the spectral response acceleration over 1 second period, with $5 \%$ attenuation in bedrock $\left(S_{I}\right)$ for a $2 \%$ probability of being exceeded in 50 years 


\subsection{Time History (TH) Method}

This analysis is very complicated and requires many calculations; therefore, SAP2000 software was used. Structural properties needed in $\mathrm{TH}$ analysis covers a mass, stiffness, and damping of structure. The structural mass was calculated according to the minimum load for the design of buildings and others [10]. The stiffness of the structure is influenced by its properties presented in Table 2, while the damping is determined by $5 \%$.

The earthquake load input in this analysis used a strongmotion record of the Yogyakarta Earthquake in 2006 [11]. The strong motion record of the Yogyakarta earthquake is displayed in Fig. 8. In TH analysis, several earthquake inputs must be analyzed, and one of them is the El Centro earthquake. The acceleration spectra response of the earthquake input must be matched to the spectra response characteristics of the site [9]. This study takes the Yogyakarta earthquake's accelerogram as an earthquake input, while the spectra response of the Yogyakarta Earthquake is similar to the El Centro earthquake (see Fig. 9). Besides, Yogyakarta Earthquake also indicates a suitably with the site characteristics because it is located in Yogyakarta.

TH analysis using SAP2000 software produces deflection and story horizontal force in each mode shape. Furthermore, the base shear and story shear can be determined by processing the SAP2000 output. The base shear accumulates of all story horizontal forces, while the story shear is the horizontal forces in one story.

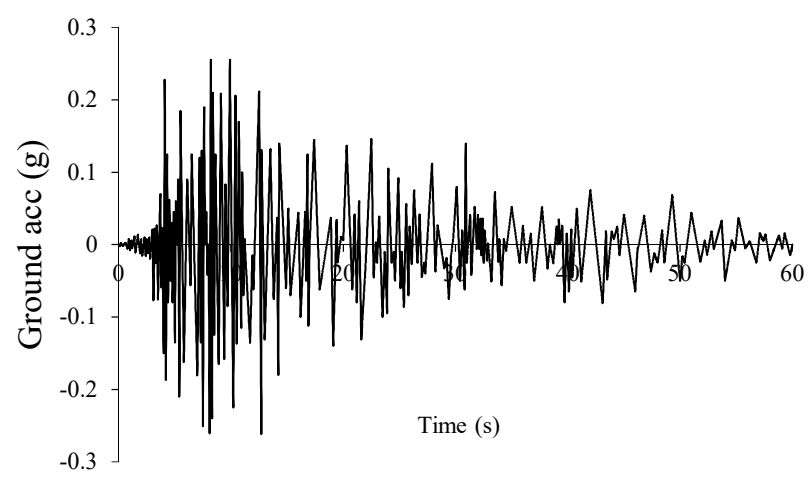

Fig. 8. Strong motion record of Yogyakarta Eathquake (2006)

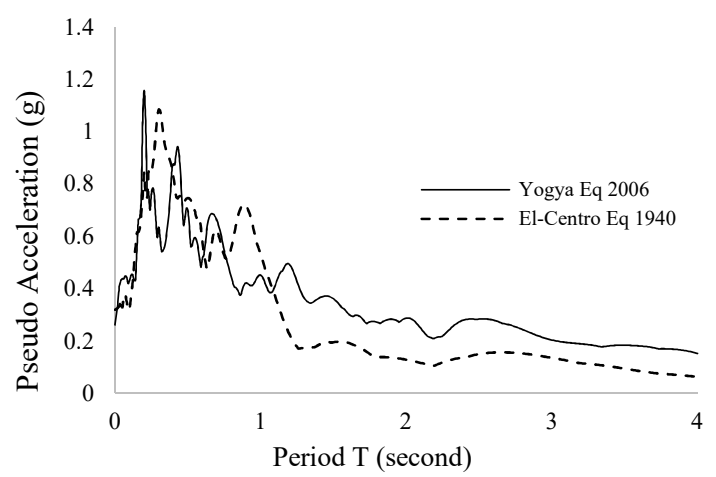

Fig. 9. Comparison of spectra response between Yogyakarta Earthquake and El Centro Earthquake

\section{RESULTS AND DISCUSSION}

For validation purposes, this study compared the results of ES and TH analyses, consisting of story horizontal force $(\mathrm{Fi})$, base shear $(V)$, story shear force $(V i)$, and story displacement (di).

\subsection{Story Horizontal Forces (Fi)}

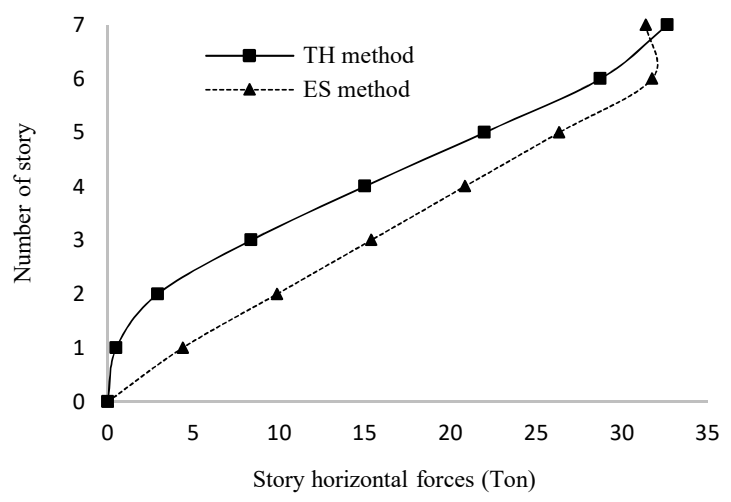

The

story horizontal forces (Fi) has been generated from the SAP 2000 analysis. The result comparison between the ES and TH analysis is presented in Fig. 10-13.

Fig. 10. The story horizontal forces $(F i)$ of the 7-story building

Fig. 10 presents the story's horizontal forces of the 7-story building. The story horizontal forces provided by the ES method is higher than the TH method for almost all stories. These results indicate that the ES method is acceptable to design a 7-story building since the value of story horizontal forces using this method is higher than the TH method. This result follows Nasution and Teruna [6], stating that the equivalent static method can analyze 7-story buildings. For a 9-story building (Fig. 11), the ES method shows conservative results, but only for structures up to the fourth floors, not for structures above it. If the 9-story building is designed using the ES method, it has the potential to collapse due to an earthquake on the fifth or higher floors. Hence, the ES method is not acceptable for the design of 9-story structures.

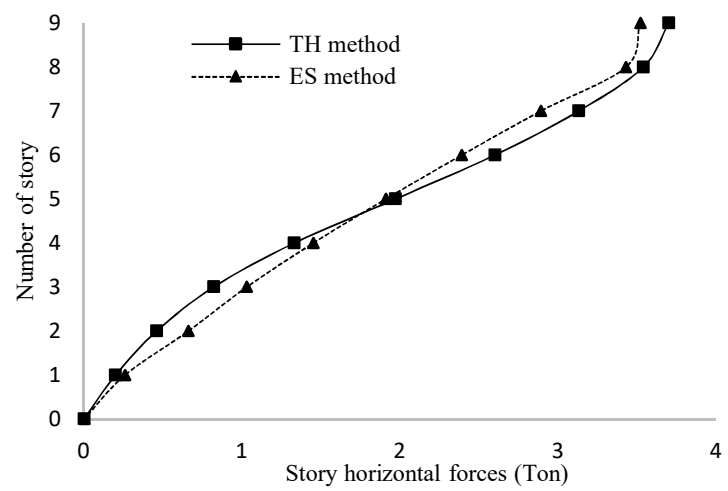

Fig. 11. The story horizontal forces $(F i)$ of the 9-story building 


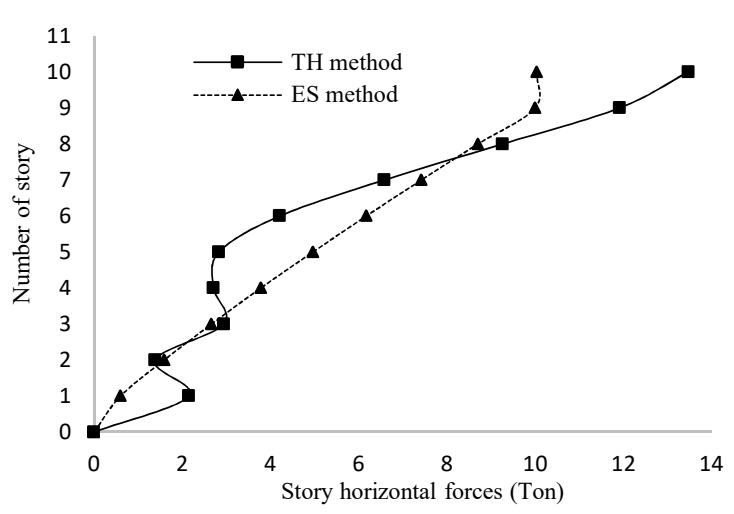

Fig. 12. The story horizontal forces $(F i)$ of the 10-story building

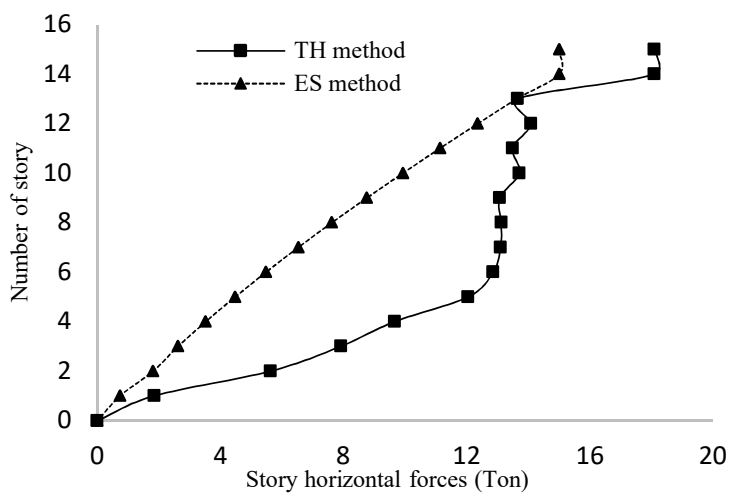

Fig. 13. The story horizontal forces $(F i)$ of the 15 -story building

The story horizontal forces analyzed by the TH of the 10 and 15-story buildings (Fig. 12 and 13) are increasingly irregular in shape. Hence, the results of ES analysis are suspected to increasingly unable to pass the requirements. It is because TH analysis considers all modes, while ES analysis only considers the first mode. Therefore, the ES analysis is not recommended for high structures analysis [12]. The essential structures must be analyzed by the TH method as it predicts the structural response more accurately than the ES method [7]. This research discovered that the story horizontal forces from ES analysis of the 9-story building or higher were not greater than $\mathrm{TH}$ analysis on all stories. This finding recommends that the ES is not an acceptable method for analyzing the earthquake load of 9-story and higher buildings.

\subsection{Base Shear (V)}

The base shear of all structural models analyzed by ES and TH methods is presented in Fig 14. The base shear value of the ES method for the 7-story building is higher than that of the TH method but is slightly the same for the 9 and 10-story buildings. Nevertheless, the base shear of ES analysis is much lesser than TH analysis in the 15 -story building. In other words, the base shear resulting from the ES analysis shows a significantly higher value for only the 7-story structure. In the previous study, Haque et al. [13] discovered that the base shear value of an 11-story building using dynamic analysis was higher than static analysis. Accordingly, the ES method is not recommended for earthquake load analysis of higher than a 7 -story building. It should also be noted that base shear value increases significantly in high seismicity regions and soft soil conditions [14].

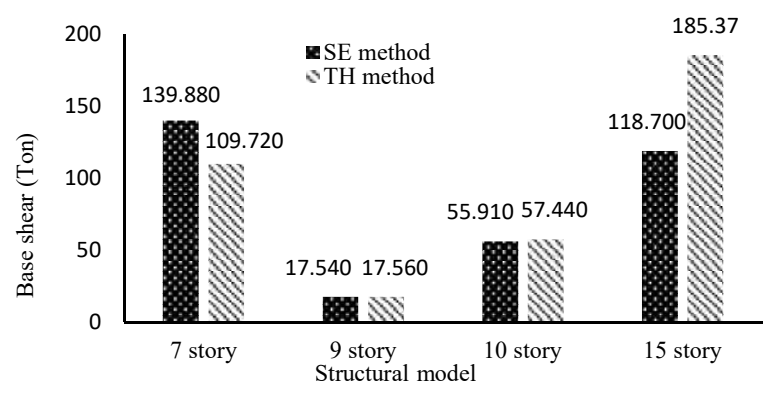

Fig. 14. The resume of base shear value

Higher than 7-story building have potential damage under an earthquake if designed using the ES method for not meeting the earthquake-resistant structure requirements. This result indicates that the ES method is inadequate for base shear analysis of the 9-story and higher buildings. Nasution and Teruna [6] also stated that ES is an adequate method to analyze the base shear of 7-story buildings, but the TH method is more accurate.

\subsection{The Story Shear Forces}

A comparison curve of the story shear forces between two methods is shown in Fig. 15-18. The story shear forces of the 7-story building resulted from ES analysis is larger than TH analysis in all stories (Fig. 15). For the 9 and 10-story buildings, the value of the story shear force is nearly the same between the two methods, TH and DH (Fig. 16-17). However, on a higher than 10-story building, the ES value is smaller than the TH value for the story shear force, as presented in Fig. 18 (for 15-story).

From Fig. 15 and 18, it can be observed that the largest difference of the story shear value is found in the bottom story. This condition demonstrates the prediction of the failure location. If a higher than 10 -story structure is designed using the ES method, the structure is likely to be damaged, especially at the base level. The difference in the story shear value at the base of the 15 -story is the largest, reaching $56.2 \%$. This result confirms a consideration stated that the ES is not an applicable method for a 9-storey structure and higher.

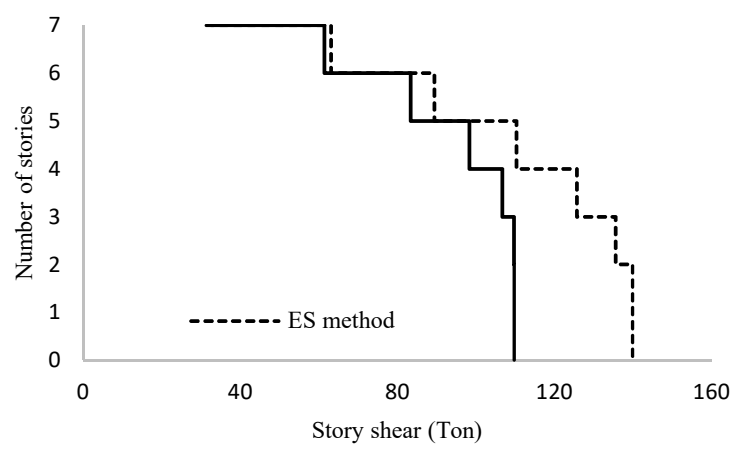

Fig. 15. The story shear forces of the 7-story building 




Fig. 16. The story shear forces of the 9-story building

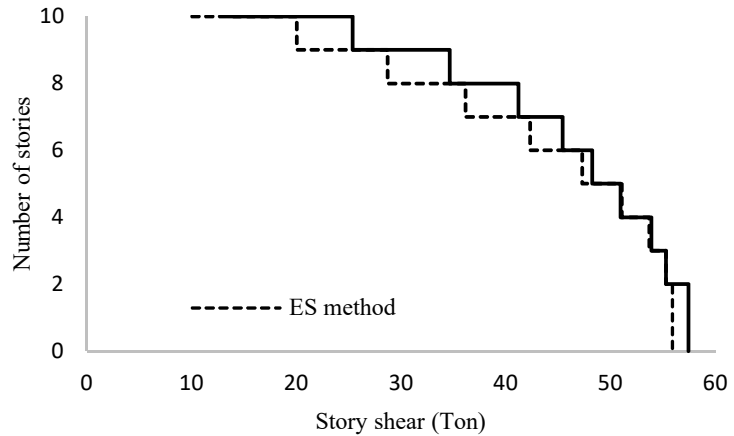

Fig. 17. The story shear forces of the 10 -story building

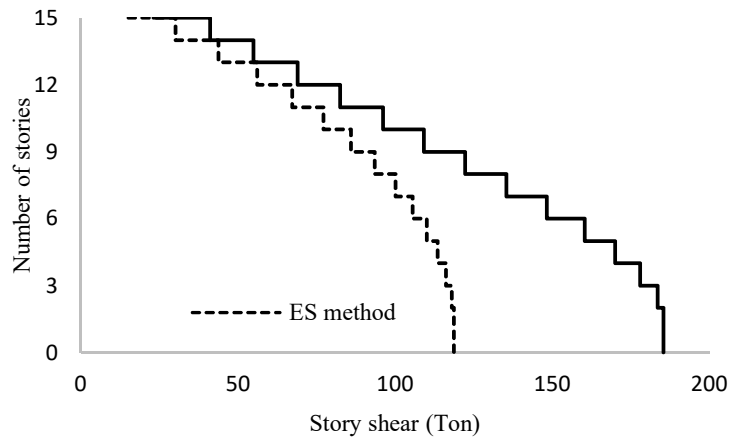

Fig. 18. The story shear forces of the 15 -story building

\subsection{Story Displacement}

This study also investigates the story displacement of the structure. Fig. 19 - 22 present the displacement on each story from 7, 9, 10, and 15-story buildings. The story displacement of the 7-story building (Fig. 19) by ES is greater than the TH method. If the ES method results are used in structural design, it will produce an uneconomic design due to the higher design price exceeding the needs, where the real needs are shown from the TH analysis results [14], [15].

However, it is nearly the same for both ES and TH on the 9 and 10-story structures (Fig. 20 and 21). The story displacement of the 15-story structures resulted from the ES is smaller than from the TH method, as presented in Fig. 22. The greatest difference value is on the top of the 15-story structure, reaching $42 \%$. These results are consistent with the statement of Kakpure and Mundhada [14] and Magar et al. [16], mentioning that the difference in displacement values between the result of equivalent static and dynamic analysis is significant in the top story or roof.

In short, the ES method is not recommended for earthquake resistant structure design of the 9-story and higher structures. Ahmed and Kishore [17] also reported that story displacement increases with the increase in numbers of stories. It is minimum at the base and maximum at the top floor. Furthermore, Murlidhar and M [15] stated that static analysis is inadequate for high-rise building designs, especially for essential structures, because time history analysis predicts structural responses accurately.

The comparison between the results of ES and $\mathrm{TH}$ analyses in terms of story horizontal force (Fi), base shear (V), story shear forces $(\mathrm{Vi})$, and story displacement $(\mathrm{di})$ was explained. The results revealed that the ES method was secure for the 7-story building design, but not for higher buildings. This study recommends using the $\mathrm{TH}$ method in the structure design higher than 7-story. It is consistent with the statement that TH analysis is an elegant tool to visualize the performance level of a building under a given earthquake, and ES analysis is insufficient for high rise buildings [18]. Besides, Kumar et al. [19] proposed that the response spectrum method is more suitable for the buildings with a regular mass distribution and stiffness with extra height.

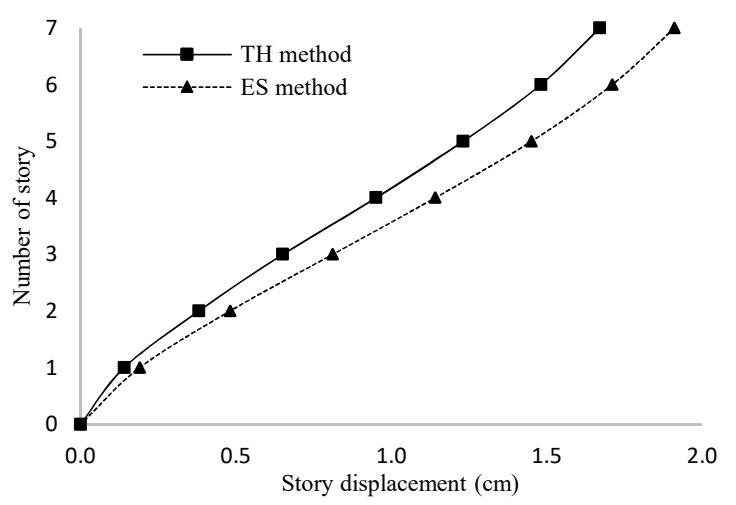

Fig 19. The story displacement of the 7-story structure

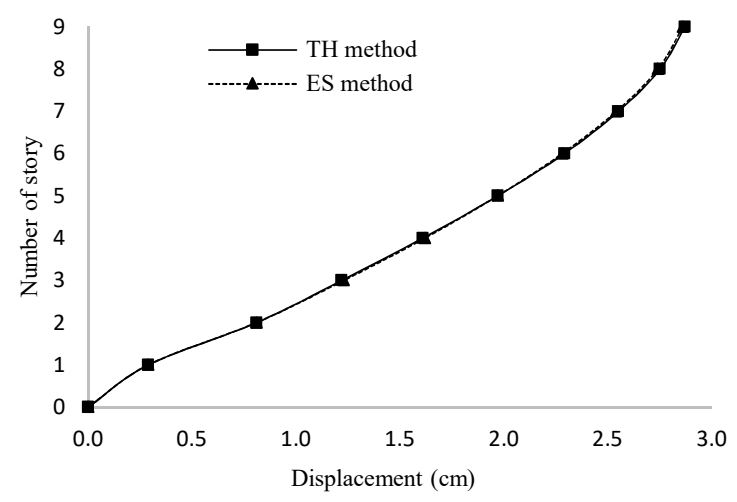

Fig 20. The story displacement of the 9-story structure 


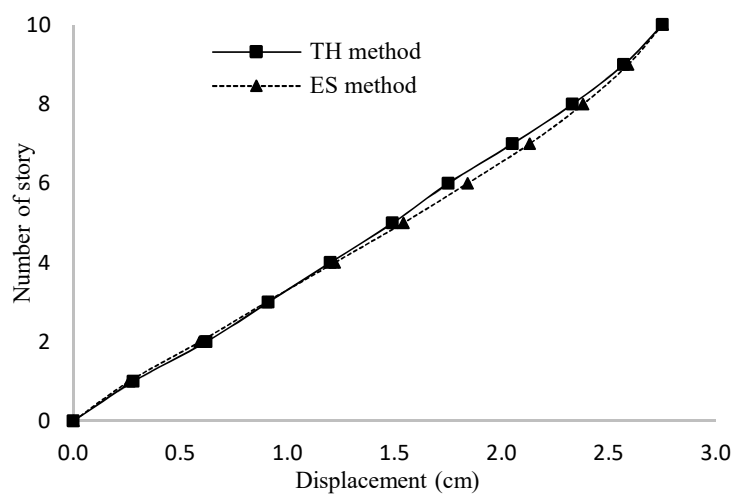

Fig 21. The story displacement of the 10 -story structure

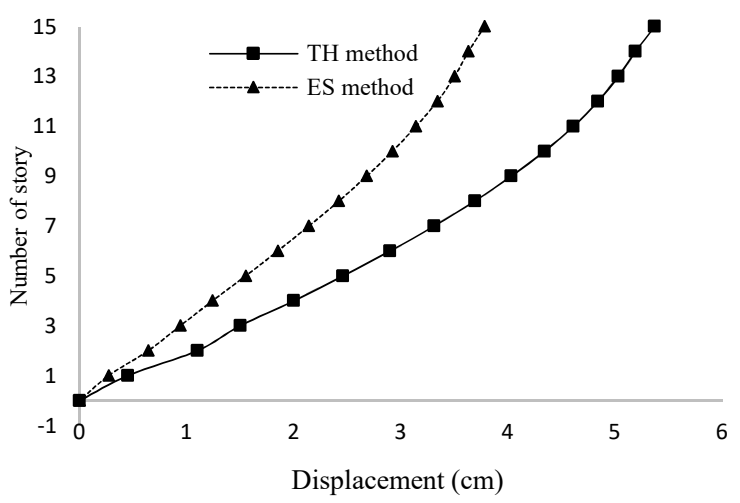

Fig. 22. The story deflection of the 15 -story building

\section{CONCLUSIONS}

Structural responses of the 7, 9, 10, and 15-story buildings, including story horizontal forces, base shear, story shear forces, and story displacement, have been obtained. Structural response analysis was carried out using two methods, ES and $\mathrm{TH}$. The ES analysis result was greater than that of the TH analysis since it was calculated in the structural design. The analysis of base shear, horizontal story force, and displacement revealed an exact result. The ES method was not acceptable for a structural response analysis method for 9story or higher buildings. Therefore, the 9-story or higher buildings must be analyzed using the TH method. If the 15story building is analyzed using the ES method, the potential damage is estimated at the bottom of the building. This result can be used as a consideration to choose an analysis method in earthquake-resistant structural design.

\section{ACKNOWLEDGMENT}

The authors gratefully acknowledge Universitas Muhammadiyah Yogyakarta, especially to the Civil Engineering Department for providing the support.

\section{REFERENCES}

[1] Widodo, Respons Dinamik Struktur Elastik, $1^{\text {st }}$ ed. Yogyakarta: UII Press, 2001.
[2] M. Paz and W. Leigh, Structural Dynamics: Theory and Computation, update with SAP2000, $5^{\text {th }}$ ed., vol. 5. London: Kluwer Academic Publisher, 2004.

[3] D. J. G. Kori, "Earthquake Lateral Force Analysis," Haveri, 2019, Accessed: Apr. 14, 2019. [Online]. Available: http://www.sginstitute.in/activities/Civil/Day_6_2.pdf.

[4] A. S. Patil and P. D. Kumbhar, "Time History Analysis of Multistoried RCC Buildings for Different Seismic Intensities," International Journal of Structural and Civil Engineering Research IJSCER, vol. 2, no. 3, pp. 194-201, Aug. 2013.

[5] BSN, Tata Cara Perencanaan Ketahanan Gempa untuk Struktur Banguna Gedung dan Non-gedung, vol. SNI 1726:2012. 2012, p. 138.

[6] F. Nasution and D. R. Teruna, "Perbandingan Analisis Statik Ekivalen dan Analisi Dinamik Ragam Spektrum Respons pada Struktur Beraturan dan Ketidakberaturan Massa sesuai RSNI 03-1726-201X," Tugas Akhir, USU Medan, Medan, 2015.

[7] B. Bagheri, E. S. Firoozabad, and M. Yahyaei, "Comparative Study of the Static and Dynamic Analysis of Multi-Storey Irregular Building," 2012.

[8] R. Faizah, "Studi Perbandingan Pembebanan Gempa Statik Ekuivalen dan Dinamik Time History pada Gedung Bertingkat di Yogyakarta," Semesta Teknika, vol. 18, no. 2, pp. 190-199, Aug. 2016.

[9] BSN, Tata Cara Perencanaan Ketahanan Gempa untuk Struktur Bangunan Gedung dan Non-gedung, vol. SNI 1726:2019. 2019, p. 254.

[10] BSN, Beban Minimum untuk Perancangan Bangunan Gedung dan Struktur Lain, vol. 1727:2013. 2013, p. 196.

[11] A. S. Elnashai, S. J. Kim, G. J. Yun, and D. Sidarta, "The Yogyakarta Earthquake of May 27, 2006," Mid-America Earthquake Center (MAE), America, MAE Center Report 0702, 2006.

[12] R. Faizah, "Analisis distribusi vertikal gaya gempa dan implikasinya pada respons bangunan bertingkat, MS Tesis, Magister Teknik Sipil Universitas Islam Indonesia, 2013," Tesis, UII, Yogyakarta, 2013.

[13] S. A. Haque, T. Haque, S. Sanjida, and Y. Masud, "Static \& Time History Analysis of RCC Structure: A Review," Chittagong, Bangladesh, December 2016, p. 6.

[14] G. G. Kakpure and A. R. Mundhada, "Comparative Study of Static and Dynamic Seismic Analysis of Multistoried RCC Building by ETAB: A Review," International Journal of Emerging Research in Management \&Technology, vol. 5, no. 12, p. 5, Desember 2016.

[15] W. R. Murlidhar and P. R. M, "Comparative Study of Various Seismic Analysis Methods for Rc Structure," IJERA, vol. 07, no. 06, pp. 30-36, Jun. 2017, doi: 10.9790/9622-0706033036.

[16] S. R. Magar, D. H. Tupe, and G. R. Gandhe, "Comparative Analysis between Static and Non Linear Dynamic Analysis of Irregular and Regular Building," IOSR Journal of Engineering (IOSRJEN), vol. 7, no. 11, pp. 18-25, Nov. 2017.

[17] M. M. Ahmed and G. Kishore, "Time History Analysis of Multi Storey Building for Highrise Structures," International Journal of Innovative Technology and Research, IJITR, vol. 6, no. 6, pp. 8970-8972-8972, Dec. 2018.

[18] P. Chandrakar and D. P. S. Bokare, "A Review - Comparison between Response Spectrum Method and Time History Method for Dynamic Analysis of Multistoried Building," International Journal of Science and Research (IJSR), vol. 6, no. 5, pp. 244 247, Mei 2017.

[19] N. Kumar, D. Kushwaha, M. C. Maurya, and R. K. Sharma, "Comparative Study of Equivalent Lateral Force Method and Response Spectrum Method for OMRF Multistory Building A Review Paper," International Research Journal of Engineering and Technology (IRJET), vol. 05, no. 07, p. 8, 2018. 